\title{
New Iridoid Esters from the Roots of Patrinia scabiosaefolia
}

\author{
Eun Jin Choi, Qing-He Liu, Qinglong Jin, Ji Eun Shin, Jongki Hong,; Dong Gun Lee, and Eun-Rhan Woo
}

\author{
College of Pharmacy, Chosun Chiversin, Gwangiu 501-759, Korea. ${ }^{*}$-mail: wooerächosun ac.kr \\ 'College of Pharmacy Kinth Hee Universitw, Seoul 130-701, Korea \\ iSchool of Life Sciences and Biotechnologv, College of Natural Sciences. Kvungpook National Chiversity, \\ Daegu 702-701. Korea \\ Received April 12, 2009, Accepted.April 25, 2009
}

\begin{abstract}
Key Words: Patrinia scabiosaefolia, Valerianaceae. 1-Isovaleryloxy-3.8-dimetlly losy-4-(3-methyl-butyryloxymethyl)-8-hyddroxymethyl-cyclopenta-4,6-diene[c]pyran: patriscadoid I (1). 1-Isovaleryloxy-3-methyloxy-4-(3-methy l-butyry loxy methy 1)-8-hydroxymethyl-8-hydroxy-cyclopenta-4,6-diene[c]py ran; patriscadoid II (2). Iridoid
\end{abstract}

Patrinia scabiosaefolia Fischer (Valerianaceae) is a perennial plant distributed across mountainous regions and fields of Korea. Japan and China. ${ }^{3}$ The roots of $P$. scabiosaefolia have been widely used in traditional medicine for the treatment of edema, appendicitis and inflammation. 2 Previous phytochemical work on the roots as well as aerial parts of $P$. scabiosaefolla has resulted in the isolation of saponins. ${ }^{3-5}$ coumarins. ${ }^{6}$ iridoids, and triterpene lactone. ${ }^{8}$ In addition, Bae et al. reported the isolation and characterization of two iridoid diesters. patridoid I and II from the whole plant of $P$. sanictlaefolia, a closely related species. In a continuation of the phytochemical study on $P$. scabiosaefolia, we now report the isolation and structural elucidation of two new iridoids, l-isovaleryl-

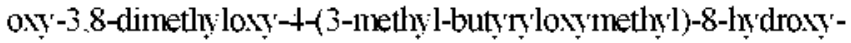
methyl-cyclopenta-4,6-diene[c]py ran. patriscadoid I (1) and 1-isovaleryloxy-3-methyloxy-4-(3-methyl-butyryloxymethyl)8-hỵ'droxy methy' l-8-hỵd droxy-cyclopenta-4,6-diene[c]pyran.



$\begin{array}{ccccc} & \mathrm{R}_{1} & \mathrm{R}_{2} & \mathrm{R}_{3} & \mathrm{R}_{4} \\ 1 & \mathrm{OCH}_{3} & \mathrm{H} & \mathrm{CH}_{2} \mathrm{OH} & \mathrm{OCH}_{3} \\ 2 & \mathrm{OCH}_{3} & \mathrm{H} & \mathrm{CH}_{2} \mathrm{OH} & \mathrm{OH}\end{array}$

Chart 1. Structures of Compounds 1 and 2 from Patrinia scabiosaefolia patriscadoid II (2).

The roots of $P$. scabiosaefolia were extracted with $\mathrm{MeOH}$ under reflux. The $\mathrm{MeOH}$ extract was suspended in water and then partitioned sequentially with equal volumes of dichloromethane, ethyl acetate, and $n$-butanol. A methylene chloride soluble fraction of the $\mathrm{MeOH}$ extract was purified by silica gel. MCI gel CHP 20P. and Lichroprep RP-18 column chromatography yielded two new iridoids. patriscadoid I, and II (Chart 1).

Compound 1 was obtained as a yellow oil and gave a molecular ion peak at $m z+49.2165[\mathrm{M}+\mathrm{Na}]^{+}$in the HR-FABMS corresponding to the elemental formula $\mathrm{C}_{22} \mathrm{H}_{34} \mathrm{O}_{8}$ and indicating five degrees of unsaturation. The IR spectrum indicated the presence of a hydroxyl group $\left(3450 \mathrm{~cm}^{.1}\right)$ and an ester group $\left(1730 \mathrm{~cm}^{-1}\right)$. The ${ }^{1} \mathrm{H}-\mathrm{NMR}$ spectrum of 1 exhibited signals due to two olefinic protons at ô $6.88(1 \mathrm{H}, \mathrm{d} . J=5.5$ $\mathrm{Hz})$ and $6.3 \mathrm{~L}(\mathrm{lH} . \mathrm{d} . J=5.5 \mathrm{~Hz})$. two acetalic protons at $\delta 6.24$ $(1 \mathrm{H} . \mathrm{d} . J=7.0 \mathrm{~Hz}$ ) and $\delta 5.22(1 \mathrm{H} . \mathrm{s})$, one metline proton at $\delta 2.8 \mathrm{l}(\mathrm{lH} . \mathrm{d} . J=6.5 \mathrm{~Hz}$ ). and an isolated hydroxymethyl protons at 03.69 and 3.60 (eacl, $\mathrm{d}_{,} J=11.5 \mathrm{~Hz}$ ). The presence of these functional groups was further supported by ${ }^{12} \mathrm{C} \mathrm{NMR}$ signals for 1 observed at $\hat{o} 132.6(\mathrm{CH}) .138 .8(\mathrm{CH}) .90 .4(\mathrm{CH})$. $98.5(\mathrm{CH}), 45.4(\mathrm{CH})$. and $67.2\left(\mathrm{CH}_{2}\right)$. Furthermore, the ${ }^{\mathrm{l}} \mathrm{H}$ and ${ }^{13} \mathrm{C}-\mathrm{NMR}$ spectra showed two doublet methyl signals at $\delta$ 0.94 (d. $J=6.5 \mathrm{~Hz}), 1.00(\mathrm{~d} . J=6.5 \mathrm{~Hz}$ ), two metlyylene signals at $\delta 2.15 .2 .07$. two methine signals at $\delta 2.26 .2$. 19 (each. dd. $J=7.5 .4 .5 \mathrm{~Hz}$ ), and a carbonyl carbon signal at $\delta 172.0 .172 .8$. indicating two isovalery loxy ester moieties which were confirmed by the 2D COSY of 1 . The ${ }^{1} \mathrm{H}-\mathrm{NMR}$ spectrum also exhibited two methoxy protons at o $3.4+4$ and 3.09. These data suggested that the structure of $\mathbf{1}$ was an iridoid skeleton similar to that of patridoid II. The connectivities of 1 were established by the HMBC spectrum. Correlations between the signals at oे $6.88(\mathrm{H}-6) / 6.3 \mathrm{l}(\mathrm{H}-7)$ and $\delta$ 45.4 (C-9). $\delta 2.81$ $(\mathrm{H}-9)$ and $\delta 67.2(\mathrm{C}-10)$ confirmed that the isolated hydroxymethyl group was connected to $\mathrm{C}-8$. In addition. correlations between signals ô $6.2+(\mathrm{H}-1)$ and ô $172.0\left(\mathrm{C}-1^{\prime}\right)$, $\hat{\delta} 4.87(\mathrm{H}-\mathrm{l} \mathrm{la}) / 4.65$ (H-l lb) and $\delta 172.8$ (C-l") indicated that the isovalery loxy group was connected to $\mathrm{C}-\mathrm{I}$ and $\mathrm{C}-4$. respectively. The positions of the methoxy groups at C-3 and C-8 were confirmed by cross peaks between $3.44\left(\mathrm{OCH}_{3}\right)$ and 


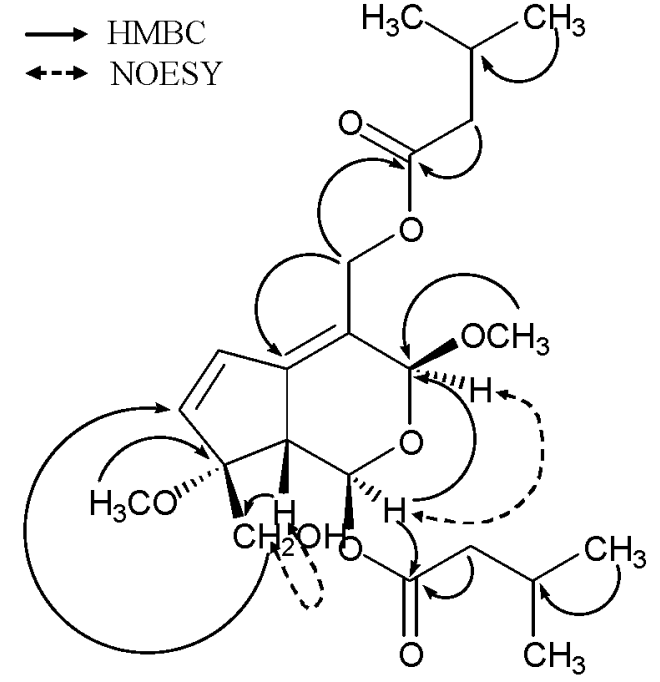

Figure 1. Key HMBC and NOESY correlations for 1.

ò $98.5(\mathrm{C}-3)$ and between $\delta 3.09\left(\mathrm{OCH}_{3}\right)$ and $\delta 87.7(\mathrm{C}-8)$. Concerning the stereochemistry of 1 , the $\beta$-orientation of the isovaleryloxy group at $\mathrm{C}-\mathrm{I}$ was determined by comparison of the NMR spectral data with those reported in the literature and NOESY experiments. ${ }^{10}$ The coupling constant of $\mathrm{H}-\mathrm{I}$ of 1 compared with that of patridoid II. isolated from $P$. samiculaefolia, was almost the same. ${ }^{9,11 \cdot 12}$ In addition. the two methoxy groups at $\hat{0} 3.44\left(\mathrm{OCH}_{3}-3\right)$ and $\hat{0} 3.09\left(\mathrm{OCH}_{3}-8\right)$ were assigned as $\beta$ - and $\alpha$-orientations, respectively. by NOESY experiments. In the NOESY spectrum, correlation peaks between $\mathrm{H}-1(\hat{\delta} 6.24)$ and $\mathrm{H}-3(\hat{\delta} 5.22)$. and between $\mathrm{H}-9(\hat{\delta} 2.81)$ and $\mathrm{H} \cdot 10(\delta 3.69)$ indicating that $\mathrm{H}-1 / \mathrm{H}-3$ and $\mathrm{H}-9 / \mathrm{H}-10$ possess the same plane. Based on the above spectral evidence. the structure of 1 was elucidated as 1-isovaleryloxy-3,8-dimethyloxy-4-(3-methylbuttyry loxy methyl)-8-hy droxymethyl-cyclopenta-4.6-diene[c]pyran. and named as patriscadoid I.

Compound 2 was obtained as a yellow oil and gave a molecular ion peak at $m z+35.2009[\mathrm{M}+\mathrm{Na}]^{+}$in the HR-FABMS corresponding to the elemental formula $\mathrm{C}_{21} \mathrm{H}_{3}=\mathrm{O}_{8}$ and indicating five degrees of unsaturation. The ${ }^{1} \mathrm{H}$ - and ${ }^{13} \mathrm{C}-\mathrm{NMR}$ spectra of $\mathbf{2}$ (see Table 1) were quite similar with those of $\mathbf{1}$. except for one additional hydroxyl group ( $\delta 83.2)$ and one less methoxyl group $(\delta 52.5)$ than 1. Comparison of the chemical shift of 2 at $\mathrm{C}-8$ and $\mathrm{C}-7$ with that of 1 revealed an upfield shift to $\delta 83.2(-4.5 \mathrm{ppm})$ and a downfield shift to $\delta 1+1.5(+2.7$ ppm), respectively, in the ${ }^{13} \mathrm{C}-\mathrm{NMR}$ spectrum. ${ }^{13}$ Moreover, the methoxyl proton peak at $\delta 3.09$ disappeared in the ${ }^{\mathrm{H}} \mathrm{H}-\mathrm{NMR}$ spectrum. The configurations of the isovaleryloxy group at $\mathrm{C}-\mathrm{I}$ and the hydroxyl group of $\mathrm{C}-8$ of $\mathbf{2}$ were equivalent with those of 1 . In the NOESY spectnum. correlation peaks were observed between $\mathrm{H}-1(\hat{\delta} 6.30)$ and $\mathrm{H}-3(\hat{0} 5.23)$, and between $\mathrm{H}-9(\hat{o} 2.86)$ and $\mathrm{H}-10(\hat{\delta} 3.74){ }^{13-14}$ Based on the above spectral evidence, the structure of 2 was elucidated as 1-isovaleryloxy-3methyloxy-4-(3-methyl-buty'ry'loxymethyl)-8-hy'droxy'methy'8-liydrosy-cyclopenta-4.6-diene[c]pyran. and named as patriscadoid II.

Patriscadoid I. and II were examined for the inhibitory effect on the IL -6 production in TNF- $\alpha$ stimulated MG- 63
Table1. ${ }^{1} \mathrm{H}$ - and ${ }^{13} \mathrm{C}-\mathrm{NMR}$ Spectral Data of Compounds 1 and 2

\begin{tabular}{|c|c|c|c|c|}
\hline \multirow{2}{*}{ No } & \multicolumn{2}{|l|}{1} & \multicolumn{2}{|l|}{2} \\
\hline & $\delta_{\mathrm{H}}$ & $\delta_{C}$ & $\delta_{\mathrm{H}}$ & $\delta_{C}$ \\
\hline 1 & $6.24 \mathrm{~d}(7.0)$ & 90.4 & $6.30 \mathrm{~d}(7.5)$ & 91.7 \\
\hline 3 & $5.22 \mathrm{~s}$ & 98.5 & $5.23 \mathrm{~s}$ & 98.8 \\
\hline 4 & & 124.3 & & 125.5 \\
\hline 5 & & 143.1 & & 1430 \\
\hline 6 & $6.88 \mathrm{~d}(5.5)$ & 132.6 & $6.69 \mathrm{~d}(5.5)$ & 130.3 \\
\hline 7 & $6.31 \mathrm{~d}(5.5)$ & 138.8 & $6.33 \mathrm{~d}(5.5)$ & 141.5 \\
\hline 8 & & 87.7 & & 83.2 \\
\hline 9 & $2.81 \mathrm{~d}(6.5)$ & 45.4 & $2.86 \mathrm{~d}(7.5)$ & 46.1 \\
\hline \multirow[t]{2}{*}{10} & $3.69 \mathrm{~d}(11.5)$ & 67.2 & $3.7+\mathrm{d}(11,0)$ & 680 \\
\hline & $3.60 \mathrm{~d}(11.5)$ & & $3.60 \mathrm{~d}(11.0)$ & \\
\hline \multirow[t]{2}{*}{11} & $4.87 \mathrm{~d}(12.5)$ & 60.1 & $4.81 \mathrm{~d}(12.5)$ & 60.1 \\
\hline & $4.65 \mathrm{~d}(12.5)$ & & $4.67 \mathrm{~d}(12.5)$ & \\
\hline$l^{\prime}$ & & 172.0 & & 172.3 \\
\hline $2^{\prime}$ & $\begin{array}{l}2.26 \text { dd }(7.5 \\
4.5)\end{array}$ & 43.3 & $2.28 \mathrm{~d}(7.5)$ & 43.5 \\
\hline 3 & $2.15 \mathrm{~m}$ & 25.5 & $2.11 \mathrm{~m}$ & 25.6 \\
\hline 4 & $1.00 \mathrm{~d}(6.5)$ & 22.3 & $1.00 \mathrm{~d}(6.5)$ & 22.4 \\
\hline $5^{\prime}$ & $1.00 \mathrm{~d}(6.5)$ & 22.3 & $1.00 \mathrm{~d}(6.5)$ & 22.4 \\
\hline l" & & 172.8 & & 172.9 \\
\hline $2^{\prime \prime}$ & $\begin{array}{l}2.19 \text { dd }(7.5 \\
4.5)\end{array}$ & 43.5 & $2.20 \mathrm{~d}(7.5)$ & 43.3 \\
\hline $3^{\prime \prime}$ & $2.07 \mathrm{~m}$ & 25.7 & $2.08 \mathrm{~m}$ & 25.7 \\
\hline $4^{\prime \prime}$ & $0.94 \mathrm{~d}(6.5)$ & 22.4 & $0.95 \mathrm{~d}(6.5)$ & 22.4 \\
\hline $5^{\prime \prime}$ & $0.94 \mathrm{~d}(6.5)$ & 22.4 & $0.95 \mathrm{~d}(6.5)$ & 22.4 \\
\hline \multicolumn{5}{|l|}{$\mathrm{OCH}_{3}(\mathrm{l})$} \\
\hline $\mathrm{OCH}_{3}(3)$ & $3.44 \mathrm{~s}$ & 55.9 & $3.46 \mathrm{~s}$ & 55.9 \\
\hline $\mathrm{OCH}_{3}(8)$ & $3.09 \mathrm{~s}$ & 52.5 & & \\
\hline
\end{tabular}

NMR data were obtained in $500 \mathrm{MHz}$ for ${ }^{1} \mathrm{H}$ and $125 \mathrm{MHz}$ for ${ }^{13} \mathrm{C}$ in $\mathrm{CDCl}_{3}$

cells. ${ }^{15}$ and the LPS-induced nitric oxide production using murine macrophage RAW 264.7 cells. ${ }^{16}$ Both compounds showed no inhibitory activity.

\section{Experimental}

General Procedures. Optical rotations were measured using an Autopol-IV polarimeter. UV spectra were obtained on a Shimadzu UV/Visible Spectrophotometer. The IR spectra were measured in $\mathrm{KBr}$ pellets using an IMS 85 (Bruker). The NMR spectra were recorded on a Varian Unity Inova 500 spectrometer. HR-FAB-MS was recorded on a JEOL JMS 700 mass spectrometer. TLC and the preparative TLC were carried out on precoated Silica gel $60 \mathrm{~F}_{254}$ (Merck. art. 5715) and RP-18 F F $_{3: 4}$ S (Merck, art. 15389) plates. Column chromatography was performed on Silica gel 60 (Merck, 40-63 and 63-200 $\mu \mathrm{m}$ ), MCI gel CHP 20P (Mitsubishi Chemical Co., $70-150 \mu \mathrm{m}$ ), and Sephadex LH-20 (Sigma. 25-100 $\mu \mathrm{m}$ ).

Plant Matelial. The roots of Patrinia scabiosaefolia were collected from the Herbarium of the College of Pharmacy, Chosun University. Korea in May 2006 and identified by Professor Emeritus Young Hee Moon of College of Pharmacy. Chosun University. Korea. Voucher specimens were 
deposited in the Herbarium of the College of Pharmacy. Chosun University, Korea (CSU-975-17).

Extraction and Isolation. The air-dried roots of Patrinia scabiosaefolia $(0.6 \mathrm{Kg})$ were cut and extracted with $\mathrm{MeOH}(3$ $\mathrm{L} \times 3)$ at $60^{\circ} \mathrm{C}$ for 3 hrs $(\times 3)$. The $\mathrm{MeOH}$ extract $(89.86 \mathrm{~g})$ was suspended in water $(1.0 \mathrm{~L})$ and then partitioned sequentially with equal volumes of dichloromethane. ethyl acetate and $n$-butanol. Each fraction was evaporated in vaccto to yield the following residues: $\mathrm{CH}_{2} \mathrm{Cl}_{2}(26.27 \mathrm{~g})$. EtOAc $(2.06 \mathrm{~g}), n-\mathrm{BuOH}$ $(21.9 \mathrm{~g})$, and water $(6+.10 \mathrm{~g})$ extract. A portion of the $\mathrm{CH}_{2} \mathrm{Cl}_{2}$ soluble fraction $(10.0 \mathrm{~g})$ was subjected to column chromatography over silica gel $(400 \mathrm{~g}$ ) eluted with an $n$-hexane-acetone $=$ $10: 1 \rightarrow 1: 1$ gradient system. The fractions were combined based on their TLC pattern to form subfractions designated as DI-D 16. Subfraction D5 (64.9 $\mathrm{mg}$ ) was further purified by column chromatography over silica gel eluted with a $\mathrm{CHCl}_{3}$ $\mathrm{MeOH}=100: 1 \rightarrow 1: 1$ gradient system to afford three subfractions (D51-D53). Subfraction D53 (10.9 $\mathrm{mg}$ ) was purified by Lichropep RP-18 column chromatography ( $\mathrm{MeOH}-\mathrm{H}_{2} \mathrm{O}=$ $2: 1)$ to give compound 1 ( $2.4 \mathrm{mg}$ ). Subfraction D52 (9.6 mg) was purified by $\mathrm{MCI}$ gel $\mathrm{CHP} 20 \mathrm{P}$ column chromatography (MeOH- $\left.\mathrm{H}_{2} \mathrm{O}=2: 1\right)$ to give compound $2(2.0 \mathrm{mg}$ ).

Patriscadoid I (1): Yellow oil. $[\alpha]^{25}:-6.0^{\circ}$ (c 1.0, MeOH): $\mathrm{UV}_{i_{\text {max }}}(\mathrm{MeOH}) \mathrm{nm}(\log \varepsilon) 277(4.20): \mathrm{IR}(\mathrm{KBr}) \mathrm{cm}^{-1}: 3450$. 1730. $1290.1100 ;{ }^{1} \mathrm{H}$ - and ${ }^{13} \mathrm{C}-\mathrm{NMR}$. see Table l: HR-FABMS $m z+49.2165[\mathrm{M}+\mathrm{Na}]^{+}$(calcd for $\mathrm{C}_{2-2} \mathrm{H}_{34} \mathrm{O}_{3} \mathrm{Na}$. 449.2151).

Patriscadoid II (2): Yellow oil. $[\alpha]^{75}$ : $+51.97^{\circ}(\mathrm{c} 0.08 . \mathrm{MeOH})$ : UV , thax $(\mathrm{MeOH}) \mathrm{nm}(\log \varepsilon) 277$ (4.10): IR (KBr) $\mathrm{cm}^{-1}: 3450$, 1730. 1290. 1100: ${ }^{1} \mathrm{H}$ - and ${ }^{17} \mathrm{C}-\mathrm{NMR}$, see Table I: HR-FAB$\mathrm{MS} m z+35.2009\left[\mathrm{M}+\mathrm{Na}^{+}\right.$(calcd for $\mathrm{C}_{21} \mathrm{H}_{3} \mathrm{O}_{8} \mathrm{Na}: 435.1995$ ).
Aclnowledgments. This work was supported by research funds from Chosun University in 2008.

\section{References}

1. Lee, T. B. Mhistrated Flora of Korea: Hyangmoon Publishing Co.: Seoul, 1993; p 714.

2. Takeda, S.: Aburada, M. Shovakngaku Zasshi 1980, 3ł, 200.

3. Choi, I. S.; Woo, W. S. Plant. Hed 1987, 53, 62 .

4. Kang, S. S.; Kim, J. S. J. Nat. Prod. 1997, 60, 1060

5. Woo, W. S.: Choi, J. S.: Seligmann, O., Wagner, H. Phytochemisty $1983,22,1045$

6. Choi, T. S.: Woo, W. S. Arch. Pham Res. 1984, 7, 121.

7. Taguchi, H.; Endo, T: Yoshioka, I.; Iitaka, Y. Chem. Pham. Bull. 1979.27. 1275

8. Yang, M. Y.; Choi, Y. H.; Yeo, H.; Kim, J. Arch. Pham Res. 2001, 2t, 416 .

9. An, B. R.: Min, B. S.: Na, M. K. Chang. H. W.: Son, K. H.; Kim, H. P.; Lee, H. K.; Bae, K.; Kang, S. S. Chen. Phom. Bull. 2003. 51,583 .

10. Murata, T; Endo, Y.; Miyase, T,; Yoshizaki, F. J. Not. Prod. 2008, 71, 1768

11. Kamel, M. S.: Mohamed, K. M.: Hassanean, H. A.; Ohtani, K: Kasai, R: Yamasaki, K. Phytochentistry 2000, 55, 353.

12. Xu, Y.-M.; McLaughlin, S. P.: Gunatilaka, A. L. J. Nat. Prod. 2007, 70, 2045

13. Kouno, I.; Koyama, I.; Jiang, Z.-H.: Tanaka, T.: Yang, D.-M. Plytochemistrv 1995, to, 1567 .

14. Liu, R. H.; Zhang, W. D; Gu, Z. B.; Zhang, C.; Su, J.; Xu, X. K. Nat. Prod. Res. 2006, 20,866.

15. Lill, Q. H.: Woo, E.-R. Nat. Prod. Sci. 2008, 14, 16

16. Pokharel, Y.: Lin, Q. H.; Oh, J. W.: Woo, E.-R.; Kang, K. W. Biol. Pham. Bull. 2007, 30, 1097. 